\title{
Thailand: beauty and globalized self-identity through cosmetic therapy and skin lightening
}

\author{
Napat Chaipraditkul*
}

Eubios Ethics Institute, Bangkok, Thailand

\begin{abstract}
Thailand has been through dynamic changes in the process of globalization, facilitating the emergence of technological advancement in improving healthcare and aesthetic surgery. Nonetheless, new advanced merchandise is marketed through advertisements and popular culture that defines what is facial and bodily perfection and fosters a mindset of improving bodily image. This paper introduces factors that affect the identity of Thai men and women in terms of beauty concepts, and some of the ethical issues involved. The concept of perfection of the body is introduced to entice people to undergo physical transformation. The paper looks at some of the Thai Buddhist norms, myths and societal expectations. Fair skin is an ongoing trend in Asia, and dark skin is generally less preferable. In addition, rhinoplastic surgery is used to reconstruct northeastern Thai noses to conform with a new 'ideal' shape. Women are more likely to be pressured into controlling their sexuality as pleasingly beautiful: neither totally seductive nor totally virtuous. Concepts of supremacy have evolved together with norms of beauty in Thai society under the shadow of western colonial advancements in Asia and inter-Asian socio-economic hierarchies. In addition to the stigmatization of certain groups because of racial and class prejudice, media images define people as 'losers' and 'winners' based upon stereotypical characteristics such as whiteness and concepts of ugliness and beauty. More bioethical reflection on the norms of beauty is needed to understand the motives for body enhancement.
\end{abstract}

KEY WORDS: Buddhism $\cdot$ Bioethics $\cdot$ Colourism $\cdot$ Farang $\cdot$ Sexuality $\cdot$ Lukkreung $\cdot$ Merits $\cdot$ Racism $\cdot$ $\mathrm{Na}$ Lao Resale or republication not permitted without written consent of the publisher

\section{INTRODUCTION}

This paper discusses the ethics of body augmentation and global beauty norms. There are a variety of drivers of ethical decision-making of consumers, including mass movements that we could call global beauty trends in achieving perfection for aesthetic ideals.

Despite the amount of public spending, beauty is seldom researched in bioethics compared to other topics. Beauty is a term often applied to images of the environment, but is also used for human beings. Many philosophers have tried to define what beauty is in terms of both environmental ethics and social ethics. Generally, the pursuit of beauty is a form of enhancement, and the same patterns of consumption that we can see in the cosmetic industry might also be applied to environmental engineering. Here I focus on cosmetic changes of humans, with some references to broader concepts of beauty.

Many decisions are made in the pursuit of beauty and aesthetics. People are now exposed to advanced medical technology and cosmetic products to improve and treat their self-perceived conditions, physical abnormalities and facial disfigurations. Women and men are exposed to the idea of attaining an 
image of beauty defined by the media, and commercials insist on proper looks and trends. Some concept of beauty is found in every human society, as something that emerges from the evolutionary history of Homo sapiens. These concepts differ over time and between cultures.

The aesthetic value of beauty has been expressed through variations of arts and styles in different parts of the world. Culture itself determines aesthetic images and ideals based on both natural surroundings and/or human-made environments. The idea of racial or ethnic beauty is particularly embedded and imposed upon cultural groups through the norms and beliefs within their aesthetic frames. Cosmetic surgery was first introduced as a way to hide facial deformity and sometimes other physical disfigurations. In the present day, however, the predominant ideals of bodily beauty are mainly limited to particular attractions that consumers seek. For example, some products are made to achieve one ideal image of beauty such as fairer and paler skin, bigger breasts or contouring a body figure to certain other ideals. These concepts of the ideal differ over time and between cultures in different countries. Here I explore some indicators and ideas of beauty and fashion.

\section{CONSTRUCTION OF THAI IMAGES OF BEAUTY}

This paper focuses on the changing concepts of culture in Thailand after contact with the Europeans whose culture has dominated most of Asia following a history of colonization over most countries. However, this is not to say that European domination was the primary cause of the Thai image of beauty. Thailand is an interesting case study because like Japan, it was never formally colonized by a European state, but it still expresses a desire to follow a number of aesthetic ideals that could be considered to be western.

Influences of Indian thought systems are evident across all of South East Asia. According to Indian caste systems and myths, the ideal of 'whiteness' played a role in Asian society in subtle forms even before European colonization of Africa, Asia and the world. In most of Asia, the fairer skin one has, the higher the future marriage partner's social class could be. The idealization of the 'perfect' marriage and fair skin is buried deeply in the minds of Asian women. Fair skin is believed to symbolize youthfulness and high quality in women. In Thailand, fair skin symbolizes health and wealth. In China, it is said that a man will find happiness and a good marriage with a fair-skinned bride (Bird et al. 2010).
In Thailand collectivism is more acceptable than individualism. The loss of face is unacceptable in front of others; therefore, in preventing the feeling of shame one must protect one's reputation ('Rak saa naa'). In Thailand, inequality is commonly accepted, and the superior provides protection and guidance to the inferiors (Hofstede 2004). The concept of the face is one determinant for defining morality and beauty of a person. According to Thai belief, beauty is a great concern of women. A beautiful proportional facial structure that could attract admirers is complimented in both men and women. Literally translated, 'Naa taa dii' means 'good eyes and face' or in other words, good looking. In general, women's bodies are considered beautiful ('Ngaam' or 'Suay'), although beauty is also associated with physical behaviour; for example, a young woman who lacks modesty, e.g. through her gestures, would be interpreted as being not beautiful (or in Thai, 'Bo Ngaam' or 'May Suay', where 'Bo' means 'not' and 'May' means 'no'). The same applies to the embarrassment or shame she may have caused under any surveillance of her peers, which emphasizes that she needs to be more respectful (Mills 1999).

Certain stereotypes are used to emphasize feminine beauty, such as 'Nang Kaew', which symbolized a woman who was owned by the king, and could gain the respect of the people through her acts of sacrifice and piety, and through her beauty and her virtue, which she possessed to glorify her husband. Buddhism determines the aesthetics and beauty of women, defining them as beautiful by virtue. A dutiful and good woman is considered to be beautiful and charming. Thus, virtue itself determines how beautiful a woman should be, more so than her external looks and appearance (Van Esterik 2000).

Theravada Buddhism is also interlinked with the Thai monarchy and nationalistic values. The national religion of Thailand is Theravada Buddhism, which provides cosmological explanations of human life and the relations of Karma, cause and effect, of previous actions along with explanations. How ones' life will unfold is determined by the idea of virtuous Karma which interprets values that determine birth and incarnations (Knutson 1994).

Both women and men must conform to social images in order to integrate into society. Beauty could thus also be used as a type of 'camouflage' in societal aspects and settings. Women as brides and wives have to increase their value by becoming more beautiful and attractive. The expression of power of women lies in beauty and femininity, as measured by society (Chaipraditkul 2012). In extending this logic, 
it could be concluded that the pursuit of beauty by women and some men is a form of empowerment which lies in beauty in order to attain social acknowledgement and acceptance.

The complexity of women's bodies is not only related to beauty but to the undesirable as well. Menstrual blood is considered to be unclean in many cultures; on the other hand, it is often viewed as the source of female power. Thus, the duality of powerplay between men and women are to be considered antithetical. In Thailand, physical interaction between monks and women is forbidden because women are considered seductive. Thai girls are taught to keep their distance from monks, whereas boys are presented to the monks and assisted to do chores for them as part of their servitude (Terwiel 1979, p. 55). Women must protect their virtue and innocence. Men as monks on the other hand are kept away from any sexual temptation. In repenting their sins, women are led to believe that continuous meritmaking ('Tum boon', i.e. the act of performing good deeds), including acts of devotion by preparing meals for monks in the early morning, will grant them a better next life. In contrast, sons who become monks can gain rewards for their parents, leading them to Nirvana, while daughters' merit-making can only give themselves a better afterlife (Ngaosyvathn 1995, p. 145-148). Thus, a mother could achieve her spiritual path by nurturing her sons and persuading them to become monks, since she could not attain it on her own (Thaweesit 2004, p. 207). This Buddhist view considers men (male) as a better incarnation or form of humanoid being than any other living form. The Buddhist Thais believe that a woman should bear all sufferings, and through her devout redemption she will be reborn in the next life as a man (Vichit-Vadakan 1994, p. 551-552). Therefore, Buddhist monks do not accept offerings directly from a woman's hands. Sexual attraction between men and women is assumed even if their interactions are nonsexual or neutral. Sexuality is expected through their connotative understanding of close relationships and interactions between males and females (Mills 1999, p. 99).

Sex in Thai Buddhism has been described by Thai writers, such as Isaramuni, as a lustful act, which fulfills desire and is known as 'Kwam-yak' (lust or want). In addition, Phra Buddhadasa, a reformist monk, explained that sex is mainly for procreation, and it can lead to suffering. Sexual desire and sexual intercourse are disgraceful and unclean, although they are considered natural. Thus, any process that interferes with the natural process of procreation, with or without contraception, is the main cause of suffering (Jackson 1993).

In contrast to the beliefs above, in Baan Na Sakae village, Thailand, it is believed that a wooden carved phallus or 'Palat khik' can be used to protect men and young boys from the attack of a female widow ghost who, in the form of a seductive young woman, could visit them in their sleep and take their life. This form of death is called 'Lai tai'. Thus, 'Pii Mae Maai', which means widow ghost, is known to be a sexual animist, who might have had a violent death. In the media, she is represented as a woman who was brutally raped and killed, and became an evil ghost. It is known that any sexual acts between a man and a woman with or without the consent of the woman is considered as a form of matrimony and marriage, regardless of whether a woman is consensual or not (Mills 1995, p. 249-251).

According to Bourdieu's (1998) Masculine Domination, the image and reputation of a woman set a price on her body and the rights to her body. In that way, men regulate that price through her appearance, chastity and virtue. Men and women communicate using symbols signified as the subject and object, agent and instruments. Men hold most symbols of capital while women are symbolized as objects whose role is to ensure perpetuation of the family lines by bearing children. There is also a common reasoning that female suffering is justified by the concept of reincarnation. Therefore, women are expected to be physically beautiful, having a price which is placed on her beauty, virtue and virginity, whereas men are not required to exhibit those traits as their power of capital. Nonetheless, beauty has been taken almost as a form of religion in the pursuit of the ideal body for women. It can measure her being, and therefore attaining the 'perfect' feminine body undeniably gives the female pleasure of being feminine (Wolf 1991, p. 134). Therefore, beauty serves as a form of societal and interpersonal acceptance.

The value of female beauty in Thailand plays an important role as a negotiator for a successful marriage and in acquiring status within a family unit. Feminine beauty is considered one of the great benefits for Thai women for acquiring love and attention from their husbands and maintaining a happy life. Nonetheless, according to Gordon (1990), women are led to believe that their pureness in body and mind determines their success through marriage and hence their destinies. In Loving to Survive, Graham et al. (1994) explained female behaviour using the term 'Societal Stockholm Syndrome', in which the 
oppressed are likely to form a relationship with oppressors who have authority over them or have held them captive. Thus, men are analogous to the captors and women are the captives; the captives play roles in which they are submissive and later come to share the same ideals with their oppressors in order to survive (Jeffreys 2005, p. 24-27).

\section{MIXED PROGENY AND CONCEPTS OF RACE}

The globalizing world and its history of colonization resonates in life decisions throughout the world and affects our mindsets and actions. Racial hybridity could be a possible form of elevation of race and success in some societies, through the history that came along with hegemonic nationalities. Although Thailand was never officially colonized by the British or French empires that had dominated South East Asia, in the mist of the Vietnam War, large numbers of 'Lukkreung', or mixed-race children, were born from American soldiers and Thai women during the 1960s and 1970s. The paradoxical perception of the Lukkreung is either that they are children of promiscuous Thai women and American GIs, or that they are beautiful, modern, desirable, racially mixed children. The sexual relationship between a foreign man and a Thai woman is less likely to be perceived as a form of love, affection and romance.

Haritaworn's (2007) Beautiful Beasts discussed the good and bad mixes of interracial persons, and their understanding of their own identity and experiences of being. She conducted 10 interviews with women including second-generation children with interracial identity, both with and without European ancestry. The so-called 'good mixes' represent beauty and are perceived as normal and attractive middle class people to be valued. In an interview, one subject remarked that her mother was European and her Thai father was a foreign student studying abroad, insisting that she was not born of a Thai mother and European father. The image of Thai women revolves around prostitution and 'mail-order' brides to foreign men. As discussed above, saving face means protecting one's reputation and is important in Thai culture (Harrison 2001, p. 154). Although representations of Thai women in the globalized world have gradually changed, there is still a subtle discrimination that stresses working-class traits or involvement in the sex industry. Thai femininity has been portrayed such that many dark-skinned Thai women are commonly stereotyped as being of low class, with a rural background and suspicion of possible involvement with prostitution, whereas fair-skinned women are stereotyped as being upper or middle class and sexually subtle (Sunanta 2004).

Muecke (1992) conducted 5 yr of field research in the northern part of Thailand investigating prostitution, starting in 1972. She collected data from 400 families in Chiangmai, as well as from Thai researchers, along with information from Thai elites. Historically, prostitution has been prevalent for a long time in port cities of Thailand. Some families sell their daughters for economic gain (Muecke 1992, p. 893). There is a common understanding that prostitution is the pursuit of autonomy of consenting adults, mixed with the common fact that many prostitutes are minors who are forced into this situation by poor economic conditions.

Race in Thai is called 'Chat,' the connotation of which is rather ambiguous, as it includes ethnicity, citizenship and race (Weisman 2001). Paradoxically, one of the world's most famous golfers, Tiger Woods, was given honorary Thai citizenship by the Ministry of Foreign Affairs during a visit to Thailand. He became a symbol that linked success to Thai identity and was portrayed as a hybrid through his career and international golfing tournament success. His father was an African-American GI, and he was born to a non-aristocrat mother. The image of the dark skin is generally less popular than white skin, as the dark skin can symbolize degradation, considered a type of untouchability to the Thais. However, over time, such successful racially mixed progeny grabbed Thai public attention, with growing numbers of celebrities, television stars and actors of mixed origin, even though many of them do not have American GI fathers (Weisman 2001).

In Thailand cases, if another race such as Caucasian is believed to be superior to their race, this plays with feelings of insecurity by Thai persons, as doubts of our own being always challenge our perception of beauty. People may therefore pursue improvement to enhance themselves. Some may even do this for their children by having a sexual relationship with a person of another race or physique. In Black Skin, White Masks, Fanon (1952) $\mathbf{1}^{\mathbf{1}}$ describes how it is to be 'a Martinician woman'. The story is focused on Mayotte Capécia, ${ }^{\underline{1}}$ who despises

\footnotetext{
${ }^{1}$ Mayotte Capécia is depicted through Fanon's interpretation that depicts black women as being frantic for white men. She loves her white man and would obey anything. Mayotte is fascinated by his blue eyes, blond hair and light skin. She despises her own skin but later finds out that she is a half white
} 
her own skin colour and can only love a white man. It seems that the white beauty is an antithesis to her dark skin. This creates a fantasy of a black woman who willingly serves the white man's desire. In the story, Mayotte believes that the colour of her skin will grow lighter each time she washes her master's and mistress's clothing.

This story also signifies the ideal representation of European foreigners, i.e. persons of Caucasian descent, as non-slaves; thus, the psyche of the slave, as she sees herself, has succumbed to the ideal. Nonetheless, the hierachical differentiation of persons based on their skin colour is associated with slavery and subtle classism, not only in European colonization of Africa but also in Asia. The image of beauty and self-perception of physical beauty of LaoIsaan identity was acknowledged through language and the representation of Thai media. The northeastern area of Thailand is called Isaan, which is composed of many ethnic minorities, including those of Laotian ethnicity. In 1967, the assimilation of Laotians and Thais led to cultural integration in that area of Thailand. However, the popular representation of their local identity is not merely a representation of the Thai nation state; the Isaan people today are stereotyped as un-urbanized low-wage labourers and country bumpkins. As an example, a focus group interview was conducted among 3 to 5 persons on the effect of media and television shows on their identity. A Khonkean University graduate was interviewed in April 2002:

\footnotetext{
'... Isaan look is not beautiful to Thai people so if you are Khon Isaan or you have $\mathrm{Na}$ Lao, what we call $\mathrm{Na}$ Lao - Lao face or Isaan face, you cannot be famous - oh you can be famous but you cannot be what we call beautiful or handsome.' (Hesse-Swain 2006).
}

Previously, in the modernization of Thailand and national image building (when it was still called Siam), the fear of the 'western gaze' grew stronger through the discourse over European colonization. Prince Damrong, known as 'the Father of Thai history', assisted Rama V in the abolition of slavery by commencing the reformation in 1890. This was partly to avoid the scrutiny of the western gaze and perceptions of Thai civilization linking it to savagery. He reformed the narratives of Thai history in a positive light, reasoning that slavery was not related to Thai identity. He compared the definition of 2 words in Thai, 'Tai' meaning freedom, whereas it means slavery if derived from 'Dasa' in Pali. He reasoned that the discourse on slavery in Thailand was a residue of the influence of the Khmer Empire in the Ayudhaya period. He implied the independence of the defini- tion as Thai means freedom from domination (Aphornsuvan 1998, p. 177).

Hall (1997) explained that cognition consists of concepts and language. Concepts define everything that is around us and give meaning. Language constructs the conceptual map that is translated into common language and the idea becomes a visual image. Intriguingly, the representation of the $\mathrm{Na}$ Lao face and darker skin may be the antithesis of the representation of Thai national beauty. The media have represented the western ideals of beauty as equal to femininity (Saniotis 2007). Buranasak (2006) investigated the perspectives and the identity of Thai factory women in modern Thai society. A survey done in Nakorn Chaisri and Nakorn Prathom districts found that $80 \%$ of 300 interviewed women used whitening cream, meaning that only $20 \%$ claimed that they had never used whitening products. Most women claimed that having a fair face means having better job opportunities, being beautiful and trendy, and for example, 'Having a fair face was forming an identity of modernity, a woman of the new generation with an in-trend fair face' (Persaud 2005, p. 217-218).

A stereotypical belief that casts positive light on Western 'superiority', is that some Thai women prefer foreign men over Thai men. Possibily, it may be easier to find a good foreign man than a good Thai man? 'Mia Farang' refers to Thai women who are married to western men, and is used especially for northeastern or Isaan women. There are 2 main types of Thai women who marry foreign men: (1) daughters of middle class Thai households, who have studied abroad, or have worked with foreign partnerships and associates; and (2) Thai girls who work in nightlife businesses, and/or migrated from rural provinces searching for jobs and opportunities in Bangkok. Women of Naamkhlang claimed that Thai men find them unattractive, due to their darker skin, which derives from the stigmatization of Thai women by the fair-skinned Thai beauty standards (Esara 2009). According to discriminatory perspectives against dark skin, Thai men prefer women with white skin and wealth. Women need a financially secure partner for legal matrimony. Western men are thus preferred to Thai men. This has led women to attract foreigners, especially in touristic areas and in marriage agencies (Esara 2009, p.405). Although women of all races may be bound in the same category due to their gender and similarity of bodily features, women are grouped differently according to their history and are subjected to different terms. 


\section{COSMETIC PRODUCTS AND BODY AUGMENTATION}

The skin colour of a person depends on the concentration of melanin, which determines the range of darkness and lightness of the skin. A yellowish skin tone is caused by carotene acquired through the diet, whereas pinkish pigmentation of the skin is controlled by haemoglobin, in which iron determines the colour of the red blood cells. Skin colour can be altered as a result of biological determination through natural selection. However, geographical and environmental determinants, notably sunlight, are largely responsible for the distribution of different shades of skin colour (Scupin \& DeCorse 2005). The use of supplementary skin products can produced significant changes in skin colour. In the Asian market, women in countries such as Japan, Thailand, China, Korea and Indonesia are focal groups for global beauty trends. Skin whitening products are advertised to promote health and beauty (Jones 2007).

A number of chemical substances are used for skin lightening, both legal and illegal, including glutathione, hydroquinone, kojic acid, mercury and lead. The actual usage of the whitening cream depends on the users and the substance in the products themselves. The use of hydroquinone in skin whitening products is legal in the US. The formulation consists of $2 \%$ hydroquinone, which can be modified if medically indicated. In the long term, hydroquinone can cause irritation and skin sensitivity to sunlight (skin atrophy), and possible skin cancer (Rondilla \& Spickard 2007).

The regional skin-whitening craze has affected the Thais. Dr. Viroj Sindawanon, director of the Institute of Dermatology, remarked about the danger of using glutathione injections for patients. Usually, medical doctors use glutathione to cure hepatitis, but the substance has also been injected into the skin to prevent the normal regeneration of melanin cells; therefore, it is used cosmetically to produce a lighter skin (see www.thairath.co.th/content/newspaper/223168).

The improvement of self-image through physical enhancement and augmentation can build up confidence in both men and women. Cosmetics is sometimes an alternative for solving problems of confidence that people might have. In South and East Asia, most cosmetic product promotional materials denote an image of beauty as having fair or white skin. In 1997, the Japanese whitening products market was worth around USD 1.5 billion: Japanese women spent a lot of money on facial whitening products. This suggests that white skin was quite popular among the Japanese (Ashikari 2005). The trend in fairness also applies to non-facial products. New vaginal whitening products were launched in 2012, including one from Sanofi Aventis (Thailand), for which the manufacturer claimed that the product would lighten up the vaginal area within 4 wk (see www.bangkokpost.com/opinion/opinion/312264/ feminine-white-wash-goes-too-far).

In Thailand, cosmetic surgery has been practiced for decades. The most well known hospital specializing in aesthetic surgery is the Yanhee Hospital in Thonburi. This hospital attracts tourists from all around the world for its expertise in cosmetic surgery. It provides accommodation and technologically advanced surgery along with foreign language services to suit the nationality of the patients (Persaud 2005). Dr. Suphot Samrithiwanichaya, Director of Yunhee Hospital, justified one of their campaigns called 'Yunhee's Isaan girls be pretty'. He mentioned that according to a University of Khon Kaen poll of 500 respondents in 19 provinces in Northeastern Thailand, $75 \%$ wished to undergo the rhinoplastic surgery (www.siamturakij.com/home/news/display_ news.php?news_id=413339203). Therefore, cosmetic surgery could be considered a beauty treatment to cure any physical sign of abnormalities, although the line between what is normal and abnormal is very thin.

\section{DRAMA AND LITERATURE}

Skin colour as a symbol of racial beauty is an old value in the context of a long history of colourism and racism. The idea of darker skin as inferior is reflected in dramas embedded with sexist connotations. Weisman (1997) suggested a problem regarding racial hybrids in an analysis of the 'Kao Nak Na' (literally translated 'rice out of paddy'), a Thai drama on the life of racially mixed children. Through the Buddhist explanation of phenotype and collection of previous Karma, the drama discusses the problems of Thai and western hybridity which affects Thai images of beauty. It includes distortions of the traditional images of Thai identity to ones that increase solicitude. The story is mainly based on the path and lifestyle of 2 sisters named Deuan and Dam who have the same mother; Deuan is half Caucasian while Dam is part African-American. While others treat Deuan kindly because of her beautiful fair skin, Dam is humiliated because of her dark skin and is considered ugly. 
Ironically, it is Dam's unfortunate experiences and the discrimination against her, despite her kindness and perseverance, that make her the protagonist of the story. Possibly, the credibility of fair skin is likely to be more appreciated; on the other hand it resonates with the value of lighter skin among the Thais. Nonetheless, in a literary work written by Botan called That woman's name is Boonrawd (Kepner 1996), Botan mainly focuses on the economic struggles of the ambitious heroine, who is dealing with issues such as dependency and being a woman.

'Do you think any decent Thai man is going to come begging for my hand? Any Thai man who would marry me would know he could walk out any time, and nobody would think worse of him, because I was spoiled when he got me, and my family is nothing. So I've got a Farang husband, everybody says, "Yah Boonrawd- she sold herself." Is it so important for you to imagine that we love each other? That this man really cares about me?' (Kepner 1996).

The idea of race and economical segregation also stressed virtue and effected their individuality and independence. Thus, in it lies the hidden suspicion of sexual immorality.

\section{MEDIA REPRESENTATION AND ADVERTISEMENTS}

'Beauty magazines in Thailand feature the testimonials of Korean and Japanese stars in order to promote the idea of fair white skin, with slogans such as: confidence boosting, glowing enhancement and white skin miracle. There are many advertisements with similar propaganda across Asia-Pacific. It is expected that the whitener business will reach two thousand billion USD in 2011, while the most growth expectancy is in China and India'

(Author's translation from www.komchadluek.net/ detail/20120924/140792/)

Consider a few examples of a large number of commercials and advertisements that convince consumers that fair and white skin is important. For a brief period, a train poster advertisement on the Bangkok Sky train (BTS) system read in Thai 'Samrong thinaang samrab khonkao', meaning 'reserved seats for white/or light-skinned persons.' The poster advertised a beverage called 'Amino PLUS Brighten'. The poster was heavily criticized for its colourist and classist connotations on the Pantip webpage (see Supplement at www.int-res.com/articles/suppl/e013 p027_supp.pdf), which is one of the most well read web-boards in Thai. Following this public criticism, BTS removed all advertisements and posted an apologetic message on the web-board, along with

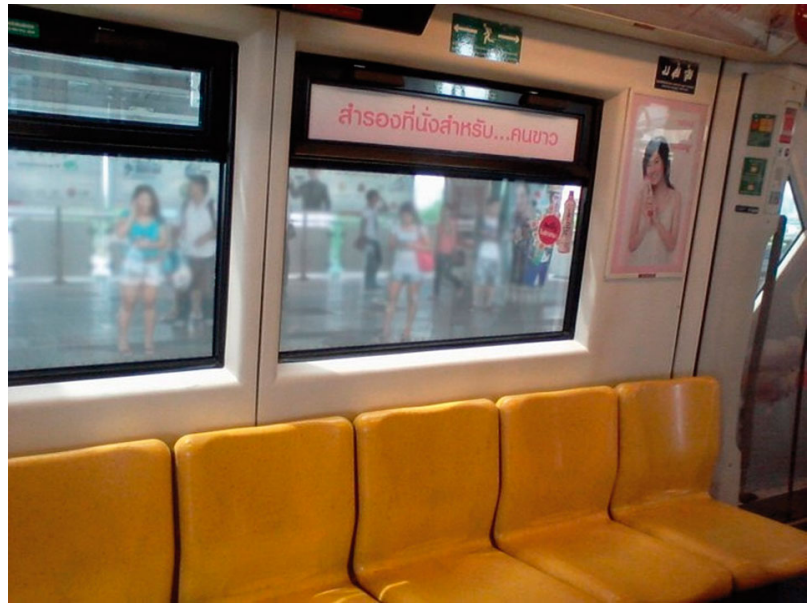

Fig. 1. Sky train poster introducing 'Amino plus brighten' whitening drink (Pantip 2011)

the Oishi group, the distributor of the product (www. matichon.co.th/news_detail.php?newsid= $1298534576 \&$ grpid $=\&$ catid $=02 \&$ subcatid $=0202$ ).

Only recently have black African women entered the fashion world, including Naomi Campbell, a television host and superstar model. Whiteness is a virtue and represents purity while blackness is considered to represent savagery; however, the combination of both worlds can also be considered beautiful in mixed-race children (Hooks 1992, p. 72-73), as discussed above. Power and desire has mediated social relations, and the beauty of the white skin discriminates against darker-skinned Thais from rural areas. Chambers (1997) suggested a type of categorization called Marked and Unmarkedness'. There are concepts that are considered unmarked. Things which are not categorized, i.e. are unmarked, include whiteness along with many other states such as maleness, middle class and heterosexuality. The concept of whiteness was not distinctively examined (Chambers 1997, p. 188). It marks women of the nonwhites. They are considered as an outgroup by ethnocentric ideals, which leads to the ignorance of coloured women, their body and experiences (Bordo 1993, p. 222).

Darker skin colour also symbolizes poverty. At present, Thailand and India are bombarded with advertisements for skin-whitening products among men (e.g. see www.guardian.co.uk/commentisfree/2010/ apr/01/skin-whitening-death-thailand?INTCMP=ILC NETTXT3487). In India, the whitening industry is valued at around US\$ 160 million a year. As an example, in a television advertisement for the whitening product 'Fair and Handsome', Sharukh Khan, a very 
popular Indian actor, supported the product, thereby raising concerns that 'Impressionable young men will get the idea that if they want to be attractive like him, they should also use [the product]' (http://news. bbc.co.uk/2/hi/7010885.stm).

The so-called 'Farang', i.e. western persons, were represented in Thai advertisements as determining and insisting on the value of being Thai. Western persons are represented as Farang, as a form of tokenism. The representation of westerners in the Thai context was linked to images pronouncing the Thai identity of people. Scottish whiskey under the 'Black Cat' brand borrowed the image of a Scottish man in a tartan kilt to promote their product, implying that Thai whiskey is a world standard approved by the Europeans, in this case a Scotsman (Nedpogaeo 2001, p. 105).

The European body portrays whiteness and attractiveness through cosmetics advertisements. In 'A Mistine Advertisement vampire', the Claire de Lune theme is played as 3 female vampires suck the blood out of an unfortunate man in a car. Four men acting as vampire hunters, run and chase them. As they chase the 3 vampires, the men come across a dark-skinned cleaning lady, leaving her dying with a cross stabbed into her mouth. Finally, they find the lair of the 3 vampires. The vampires ambush them; they run to the corner and accidentally drop a big pop art portrait of a blond woman on the floor. The light shines through the window behind them as they duck. Two of the vampires start to burn while another one is powdering her nose. The vampire hunters are awestruck by her fair face and hopelessly fall for her as they admire her by saying 'You are so white!' (See video at www.youtube.com/ watch? $v=$ GcoDfd8EB8c\&feature=player embedded.)

In addition, skin-lightening advertisements promote the white skin myth of beauty and superiority over darker skin. In another video, a curious message is given in marketing skin-whitening products, as shown in a cosmetics advertisement for a cream with which to treat freckles. This is a Mistine advertisement of a product called 'Melaclear nano Alfa Arbutin Anti-Melasma'. One of the 4 women in the story is heavily criticized for her less white skin compared to all of her friends, who suggest that a man in whom the woman is interested would lose interest in her. She therefore needs to use the cream to become lighter skinned, even though the cream is intended to treat freckles and dark spots. Thus, an artificial situation is created to inform the audience of the shame and embarrassment of having darker skin, with cream that provides treatment for undesirable traits (darker skin) as a cure for imperfection or even illness (see video at www.youtube.com/watch?v= OT2DCIXPDyk\&feature=player_embedded). Perhaps Asian consumers may find whitening products attractive and wish to remain loyal to the idea. Or it could be a symptom of a form of mild social discrimination against those who do not conform to such images.

\section{ETHICAL ANALYSIS}

A variety of papers have been written about the ethics of people pursuing cosmetic enhancement. We can argue from the ethical principle of autonomy that men and women have the right to pursue their images of physical perfection. Customers/patients can exercise their autonomy to gain access to any clothes they like, so why not any lightening products? Respect for autonomy means that they can decide what they can spend their money on. Society, in allowing people freedom to exercise their own autonomy, must respect their choices and actions (Veatch 2000). They are the actors of their own rights and perseverance in pursuit of self-determination (Beauchamp \& Walters 1994). However, there are social impacts of the combined effects of many individual persons' choices (Macer 1998), so can each person exercise his rights to pursue his image of perfection, including whiteness, fair skin or even tanned skin? Are we all really autonomous when it comes to technologies which may have a risk of harm to others indirectly (through social norms of whiteness) and even actual physical harm from side effects of some chemicals?

In the Basics of Bioethics, Veatch (2000) noted that there are 2 types of rights: positive rights and negative rights, and suggested that autonomy is linked to the negative rights which give ways to act without interruption. Even if our rights are dependent upon recognition of autonomy, we usually cannot pursue any possibility of conducting some action in practice (p. 66). In these cases, the concept of whiteness revolves around any persons who consider themselves to be in need of treatment psychologically. Beauty and white skin might not be life-threatening; however, the way we perceive our lives and ourselves affects the way we act, so we might also consider any factors that might be linked to our actions. These concepts also affect the way people view us, as described above. 
In Thailand, fortune telling is popular, despite it being considered by some to be an antithesis to the Buddhist doctrines. The future predictions of fortune telling could prescribe a possible future in response to the law of Karma directed by one's own previous action. Autonomy is less likely to be socially accepted, while social dependency has been elevated under the patriarchal monarchical society. A person could become successful by making good ethical choices and by the right opportunities they can get. Individuality and personal experience are not accepted by others as much as prescribed experiences and traditions as universal knowledge (Cook 1991). This way of thinking could say that we should accept our body as it is, without modifying it by cosmetic surgery, but it might also allow modification if that was expected by society. Nonetheless, the rights and wrongs according to the morality of the Thais is that good is an antithesis to bad, that virtue brings happiness and joy, and what is considered as wrong will lead people to suffer and face torment (Mulder 1997, p. 52-53). Therefore, what seems to be considered as an image of goodness and admiration could possibly be accepted as virtuous and what is both morally and physically beautiful. The beliefs in different incarnations are the result of good and bad Karma. Thus, it is also believed that the individual personal identity depends on the date of birth and horoscope; that their path of life could lead them to follow the dynamic planetary changes linked to all occurrences in their lifetime. Nonetheless, the idea of undergoing surgery to change the original body features has gained significant social respect in Thailand. It is influenced by male-dominated norms that shape the concepts of beauty in Thailand. Cosmetic surgery helps to provide physical enhancement and even sex change therapy. The entertainment industry and media in Thailand tend to portray many 'solutions' to women and transgendered persons (Saniotis 2007). For such services, foreigners also come to Thailand, and this is the subject of further research.

There are also health dangers, which should limit the access to some chemicals in accordance with the ethical principle of non-maleficence. If the values of pursuing white skin do not exist in a society, the product will not be sold. On the other hand, is it possible for customers to have access to quality products rather than untested cheaper whitening products if major companies do not market these products? Ethically, the risk of health issues of skin lightening should also be investigated. If the meaning of beautiful bodies was misinterpreted as always being healthy, is it possible that beauty and health could be understood as having the same meaning? This can be considered an ethical problem because the so-called stereotypical 'beautiful body' of a female is regulated by male counterparts, such as lovers, husbands and surgeons, as well as her female peers (Davis 1995). Ethically having fair and white skin should not be the only choice for women of all races, but we should encourage rather wider discourse on culture and social ideals, and concepts of insecurity.

\section{ADDITIONAL REMARKS}

The craze of skin whitening still continues, and discrimination and stigmatization, 2 principles noted in the UNESCO Universal Declaration on Bioethics and Human Rights (http://portal.unesco.org/en/ev. php-URL_ID=31058\&URL_DO=DO_TOPIC\&URL_ SEC TION=201.html), continue to be exercised. The ideas on beauty have changed, with less pressure on racial and physical features in Thailand. However, instead, they play on the prejudice that we may have on our dissatisfaction with our bodies. Our search for beauty pressures us towards changeable trends. How does each man and woman decide what is best for him/her? Sexual attractiveness is also linked to images of beauty, adding to race, which used to be the main stigma. Other concepts also play out on concepts of beauty in this contemporary world. If we can set criteria for what beauty is, we can also do so for ugliness. Western beauty was established through the beauty and physically fit bodies of statues of Olympian gods, such as Venus or the Apollo Belvedere, and these ideals also evolved in each culture. Franz Joseph Gall, a German physician (1758-1828), studied distinctive physical features through skull measurements, and indicated the link between race and beauty. He presented a contradictory picture between the European perfection of beauty and the similarity of apes to black African persons (Young 1995, p. 96). Once a clear line is made between beauty and ugliness, therefore, the inclination of the people would decide the best forms in which the idea of race is used to distinguish varieties of bodily perfection. Globalization and commerce resonates with norms of beauty, through marketing trends and fashion. As culture shapes environment, the manufacturing of products that serve human needs fulfills the economical gains and individual self-gratification. Skin lightening may be one of the trends that have affected the minds of people in different regions. Beliefs and 
values in fair skin could contribute to beauty norms and practices that need to be discovered. The social environment is affected by the global practice of beautification under cultural values and norms, which are bound in some prejudices among the 'ingroup' and the 'out-group', which media is defining in the evolution of beauty.

\section{LITERATURE CITED}

Aphornsuvan T (1998) Slavery and modernity: freedom in the making of modern Siam. In: Kelly D, Reid A (eds) Asian freedom: the idea of freedom in east and Southeast Asia. Cambridge University Press, Cambridge, p 161-186

Ashikari M (2005) Cultivating Japanese whiteness: the 'whitening' cosmetics boom and the Japanese identity. J Mater Cult 10:73-91

Beauchamp T, Walters L (1994) Contemporary issues in bioethics, 4th edn. Wadsworth publishing company, Belmont, CA

Bird D, Caldwell H, DeFenti M (2010) The quest for beauty: Asia's fascination with pale skin. In: Oglesby RA, Leblanc HP III, Adams MG (eds) Business research yearbook: global business perspectives, Vol 17(1). International Academy of Business Disciplines, Beltsville, $\mathrm{MD}, \mathrm{p} 26-32$

Bordo S (1993) Unbearable weight: feminism, Western culture, and the body. University of California Press, Berkeley, CA

Bourdieu P (1998) Masculine domination. Princeton University Press, Princeton, NJ

Buranasak J (2006) The whitening cream influences self and identity of female workers. MSc thesis, Mahidol University, Nakornprathom

Chaipraditkul N (2012) Whiteness, beauty and modernity in Thailand. MA dissertation, University of Sussex, Brighton

Chambers R (1997) Whiteness: a critical reader. New York University Press, New York, NY, p 187-203

Cook NM (1991) Thai identity in the astrological tradition. In: Reynolds CJ (ed) National identity and its defenders. Thailand 1939-1989. Monash Papers on Southeast Asia No. 25. Centre of Southeast Asian Studies, Monash University, Melbourne, p 233-260

Davis K (1995) Reshaping the female body: the dilemma of cosmetic surgery. Routledge, Abingdon

Esara P (2009) Imagining the Western husband: Thai women's desires for matrimony, status and beauty. Ethnos 74:403-426

Fanon F (1952) Black skin, white masks. Grove Press, New York, NY

Gordon L (1990) Woman's body and woman's right: birth control in America. Penguin Books, New York, NY

Graham D, Rawlings EL, Rigsby RK (1994) Loving to survive: sexual terror, men's violence, and women's lives. New York University Press, New York, NY

Hall S (1997) Representation: cultural representations and signifying practices. In: Hall S (ed) The work of representation. SAGE publications, London, p 13-75

Haritaworn J (2007) Beautiful beasts: ambivalence and distinction in the gender identity negotiations of multira- cialised women of Thai descent. Women Stud Int Forum 30:391-403

Harrison R (2001) Prostitution, politics and power: issue of the 'foreign' in western television documentaries of female sex workers in Thailand. In: Munshi S (ed) Images of the 'modern woman' in Asia. Curzon Press, Richmond, p 138-168

Hesse-Swain C (2006) Programming beauty and the absence of Na Lao: popular Thai TV and identity formation among youth in Northeast Thailand. GeoJournal 66: $257-272$

Hofstede G (2004) What about Thailand? Available at http: //geert-hofstede.com/thailand.html

Hooks B (1992) Black looks: race and representation. South End Press, Boston, MA

Jackson P (1993) Male homosexuality and transgenderism in the Thai Buddhist tradition. In: Leyland W (ed) Queer Dharma: voices of gay Buddhists. Available at www.enabling.org/ia/vipassana/Archive/J/Jackson/homo BuddhaJackson.html

Jeffreys S (2005) Beauty and misogyny: harmful cultural practices in the west. Routledge, Brighton

Jones RO (2007) Natural...the beautiful 'n' word: breaking the psychological bondage of the American standard of beauty. iUniverse, Lincoln, NE

Kepner SF (ed) (1996) Lioness in bloom: modern Thai fiction about women. University of California Press, Berkeley, CA

Knutson TJ (1994) Comparison of Thai and US American cultural values: 'Mai Pen Rai' versus 'Just do it'. ABAC J 14:1-38

Macer D (1998) Bioethics is love of life: an alternative textbook. Eubios Ethics Institute, Bangkok

Mills MB (1995) Attack of the widow ghosts: gender, death and modernity in northeast Thailand. In: Ong A, Pelets MG (eds) Bewitching women, pious men: gender and body politics in Southeast Asia. University of California Press, Berkeley, CA, p 244-273

Mills MB (1999) Thai women in the global force: consuming desire, contested selves. Rutgers University Press, New Brunswick, NJ

Muecke MA (1992) Mother sold food, daughter sells her body: cultural continuity of prostitution. Soc Sci Med 35: 891-901

Mulder N (1997) Thai images: the culture of the public world. Silkworm Books, Chiang Mai

Nedpogaeo A (2001) Global culture in the Thai media: the occidental 'Other' in TV advertisements. In: Kennedy P, Danks CJ (eds) Globalization and national identities: crisis or opportunity? Palgrave, New York, NY, p 99-111

Ngaosyvathn M (1995) Buddhism, merit making and gender: the competition for salvation in Laos. In: Karim WJ (ed) 'Male' and 'female' in developing Southeast Asia. Berg Publishers, Oxford, p 145-148

Pantip (2011) How tragic...caste in Thai society. Available at http://topicstock.pantip.com/woman/topicstock/2011/ 02/Q10263211/Q10263211.html

Persaud WH (2005) Gender, race and global modernity: a perspective from Thailand. Globalizations 2:210-227

Rondilla JL, Spickard PR (2007) Is lighter better? Skin-tone discrimination among Asian Americans. Rowman \& Littlefield, Lanham, MD

Saniotis A (2007) Changing ethics in medical practice: a Thai perspective. Indian J Med Ethics 4:24-25 
Scupin R, DeCorse CR (2005) Anthropology: a global perspective. Prentice-Hall of India, New Delhi

Sunanta S (2004) Global wife, local daughter: gender, family, and nation in transnational marriages in Northeast Thailand. PhD dissertation, University of British Columbia, Vancouver, BC

Terwiel BJ (1979) Monks and magic: an analysis of religious ceremonies in central Thailand. Curzon, London

Thaweesit S (2004) The fluidity of Thai women's gendered and sexual subjectivities. Cult Health Sex 6: 205-219

Van Esterik P (1996) The politics of beauty in Thailand. In: Ballerino Cohen C Wilk RR, Stoeltje B (eds) Beauty queens on the global stage: gender, contests, and power. Routledge, New York, NY, p 203-216

Editorial responsibility: Darryl Macer, Bangkok, Thailand
Van Esterik P (2000) Materializing Thailand. Berg Publishers, Oxford

Veatch RM (2000) The basics of bioethics. Prentice-Hall, Upper Saddle River, NJ

Vichit-Vadakan J (1994) Women and the family in Thailand in the midst of social change. Law Soc Rev 28:515-524

Weisman JR (1997) Rice outside the paddy: the form and function of hybridity in a Thai novel. Crossroads: Interdiscip J Southeast Asian Stud 11:51-78

Weisman JR (2001) The sum of our parts: mixed-heritage Asian Americans. Temple University Press, Philadelphia, PA

Wolf N (1991) The beauty myth: how images of beauty are used against women. Vintage, London

Young RJC (1995) Colonial desire: hybridity in theory, culture and race Routledge, London

Submitted: January 8, 2013; Accepted: February 20, 2013

Proofs received from author(s): June 15, 2013 